\title{
Introduction
}

\section{James Omura and the Redressing of Japanese American History}

\author{
A RTHUR A. HANSEN
}

James Matsumoto Omura (I9I2-94) was the foremost editorial voice raised against the U.S. government's World War II exclusion and incarceration of Japanese Americans. He was also the chief spokesperson decrying the Japanese American Citizens League's (JACL's) collaborative role in this shameful development. The lone Nikkei journalist to editorialize against the JACLendorsed federal policy of drafting imprisoned Japanese American citizens into the military, Omura was the first Nikkei to seek governmental redress and reparations for wartime violations of civil liberties and human rights. The heroic role he played in redeeming the tarnished repute and self-esteem of the Japanese American community has been grossly underrecognized and generally unheralded by Nikkei and non-Nikkei Americans alike. Without question, James Omura deserves to be accorded a place of honor in U.S. history commensurate with that already consecrated for resisters Gordon Hirabayashi, Minoru Yasui, Fred Korematsu, and Mitsuye Endo. ${ }^{1}$

In 2003 I authored a chapter for an anthology that honored the distinguished historian Roger Daniels's career-long contribution to Asian American history. I titled this piece "Return to the Wars: Jimmie Omura's 1947 Crusade against the Japanese American Citizens League."2 Assuredly, it had been Omura's animus toward the JACL that fueled the "wars" to which, in mid-May 1947, he was "returning" as the newly reappointed Englishsection editor of Denver, Colorado's Rocky Shimpo vernacular newspaper. ${ }^{3}$ After all, only three years previously, due in great measure to the behindthe-scenes machinations of JACL's national and regional leadership, Omura 
was flushed out of his initial four-month tenure, in early 1944, as the Rocky Shimpo's English-section editor by the U.S. government and subsequently_along with the seven leaders of the Fair Play Committee (FPC) at Wyoming's Heart Mountain Relocation Center ${ }^{4}$ —indicted, arrested, jailed, and forced to stand trial in a Cheyenne, Wyoming, federal court for unlawful conspiracy to counsel, aid, and abet violations of the military draft. Even though Omura, unlike the FPC leadership, was acquitted of this charge, his legal vindication did not prevent the Denver-area JACL power brokers from mobilizing an extralegal vendetta against him within the Nikkei community. Indeed, they so effectively harassed and demonized Omura as to make it virtually impossible for him to gain sustainable employment or to revel in the rewards of a viable social and cultural life, and these deprivations in turn hastened his 1947 divorce from his Nisei wife, Fumiko "Caryl" Omura (née Okuma). ${ }^{5}$

As discerning readers of Nisei Naysayer will discover, Omura discloses within his memoir's pages all of the above information save for what transpired during his May-December 1947 editorial stint with the Rocky Shimpo. However, by thus curtailing his autobiographical account with his being "down and out" in Denver at the end of World War II, Omura inadvertently bolsters the conventional historical narrative stamped on his life by his contemporary critics and latter-day chroniclers that his militant 1934-44 opposition to the JACL leadership of the Japanese American community and the U.S. government's wartime treatment of Japanese Americans was brought to a halt before the end of World War II. While poetically accurate, this perception violates historical veracity, since within the short interval of Omura's 1947 Rocky Shimpo tenure, he used his editorial position to a greater degree than at any time previously as a bully pulpit to criticize his nation's government, institutions, and practices, and far more often and pointedly to wage war against the JACL. As Omura promised his readers in his opening editorial column of May 16, 1947, "Nisei America: Know the Facts," he would pursue "a progressive type of journalism [to] freely criticize wherever occasion demands." He also issued a warning to the JACL leadership: "Those who have disagreed with us in the past and have been unpardonably guilty of working nefariously in the shadows may evince certain misgivings with our return to the Nisei journalistic wars. They have cause to feel uneasy."

Omura's bite more than matched his bark. His special brand of "liberalism" pervaded his columns: he praised the Committee for Industrial 
Organizations, urged Nisei to join unions, and called for the abolition of race-, sex-, and creed-based restrictions in union constitutions; ${ }^{6}$ he lauded advances toward interracial progress and advocated legislation against racial discrimination; ${ }^{7}$ and he simultaneously disparaged the dangers to democracy of both communism and its magnification as a threat by the House Un-American Activities Committee. ${ }^{8}$

Then too about one-fifth of Omura's some 120 editorial columns criticized the JACL. On May 27 he castigated its leaders for having been "autocratic and arrogant" and contended that "we need something beside the JACL." Then on June 26 he explained that the JACL did not deserve criticism for failing to "avert the Evacuation" but, rather, for its "dereliction of duty to defend with all its might the civil rights of the then discredited Nisei racial minority." Omura's July 23 editorial was more personal and pointed: "The JACL lended its helping hand to the government in a vain effort to railroad this editor to Leavenworth." In his August 2 column Omura blasted the "selfish and arrogant" JACL leadership for denying "the right of any Nisei to hold views contrary to its own."

As for the JACL's chief spokesperson, Mike Masaoka, his attitude, according to Omura's August I9 column, had been "narrow, arrogant, [and] overbearing." The other high-level JACL officials, added Omura on August 26, "cannot properly deny that they have engaged and are still engaging in invidious reprisals against the few who courageously assail the leadership of the organization." In the very next day's column, he charged that the JACL hierarchy had seen in the war "a golden opportunity to promote the organization to a position of influence."

Even at a time when, as Omura put it in his September 8 column, the JACL was "engaged in a worthwhile campaign to rectify certain injustices," he nonetheless felt that "the organization's activities in Washington are merely patterns in the design to achieve authoritarian control of Nisei society." On September io, Omura berated JACL bigwigs for "impotency," "inferiority," and a lack of "forthright leadership." Insofar as Omura had a good word for the JACL, it pertained to its stand on communism: "The Japanese American Citizens League follows the best procedure in refusing even to wink at Communism."

On December 4 a small item in the Rocky Shimpo announced that Omura had tendered his resignation and asked to be relieved of his duties as of December I5. Certainly personal finances figured heavily in Omura's decision. So also did fatigue. Throughout much of his editorship, Omura had 
operated the Omura Landscape Service, and this double duty exacted its price. As he had commented in an adversarial open letter to Togo Tanaka, a national JACL leader and a Chicago-based columnist for the Englishlanguage section of the Colorado Times, ${ }^{10}$ Denver's competitor Japanese American community newspaper, such a schedule had reduced his sleep at night to four or five hours. ${ }^{11}$ This revelation prompted a left-wing JACLer, Joe Oyama of New York, to write Omura a note: "Take the advice of an old hand, Mr. Omura. You can't do two things at one time. Otherwise, you do both badly. My advice to improve your paper is to quit and devote full time to your 'going business." 12 The December 4 Rocky Shimpo announcement by Omura signaled that he had decided to heed Oyama's sardonic recommendation about quitting his paper to enhance his budding career as a landscape architect, but surely not so as to "improve" the Rocky Shimpo. Indeed, only the prior day that paper reported Omura being named a recipient of a national rose-culture award and cited his membership in the American Rose Society, the American Horticultural Society, the National Garden Institute, and the Colorado Forestry and Horticultural Association.

Before officially abdicating his position as the Rocky Shimpo's editor, Omura fired a volley of parting shots, aimed first at the JACL and then at the Colorado Times and its most opinionated columnist, Minoru Yasui, a staunch JACL advocate and Omura's arch-nemesis. On December 3 Omura dedicated his editorial to the possible role that liberals in the JACL could play to reform the organization. Such liberals, he claimed, had frequently solicited him to join the organization and assist in this process. But he had declined on the grounds that if the leadership had rejected his advice from outside the JACL's ranks, it was absurd to think that it would listen to him as a member. Still, the liberal element in the JACL represented the best hope for reforming the organization. Institutional salvation could only come about, though, if the leadership recanted its wartime performance and revised its current campaign in Congress so that the legislation sought would materially help a majority of the Nisei and not merely a chosen few.

Having dealt with the liberals in the JACL, Omura then turned in his December 9 editorial to the "fanatics" within the organization. He charged that such individuals, who pervaded the league's top leadership, presented the view that the JACL was engaged in a high calling and could therefore demand unqualified allegiance from other Nisei. But the JACL's numerically small membership (six thousand out of a total Nisei population of eightyfive thousand "eligible" Nisei, including thirty thousand Nisei war veterans) 
proved that such fanaticism lacked popular appeal. Because the fanatical leaders, whom Omura saw as being both intelligent and unbalanced in their organizational devotion, had made (and continued to make) so many personal sacrifices to promote the JACL, they were virtually immune to and even resented constructive criticism. In the long run, concluded Omura, the liberals in the JACL would have to reform the organization before the fanatics destroyed it.

In his editorial assessment of the state of "Denver Nisei Leadership" for the December I2 issue of the Rocky Shimpo, Omura drew a damaging comparison between his newspaper's approach to this state of affairs and that of the Colorado Times. Whereas the rival Denver vernacular deplored

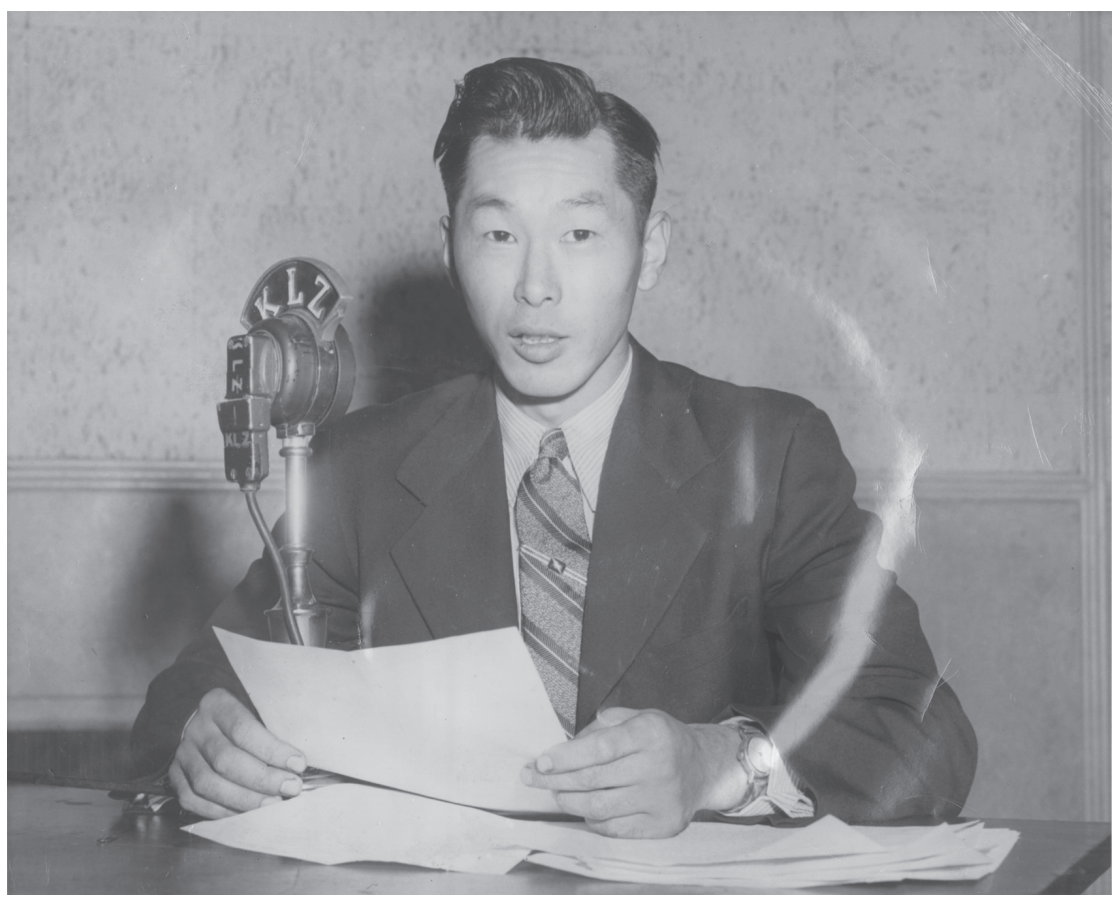

F I G U R E I. Jimmie Omura, "Liberty Calling" program on KLZ radio, Denver, Colorado, October 12, 1947. In the first of two broadcasts on "Japanese Americans' problems in Denver," the Rocky Shimpo editor stressed discrimination faced by Nikkei in employment, education, and housing. In contrast, the second broadcast's featured speaker, Colorado Times publisher Fred Kaihara, maintained that discrimination in no way hampered Denver's Japanese American community. Omura Papers, Green Library, Stanford University. 
the inadequacy of the city's Nisei leadership, it nonetheless defended it and shielded it from the Rocky Shimpo's criticism. This craven policy by the Colorado Times was anathema to Omura, who had operated the Rocky Shimpo on the premise that what should be courted was truth and democratic progress, not public favor. "Ours," exulted Omura, "is the journalism of the Bennetts, the Danas, the Goulds - the men who built American journalism and lifted it from the Milquetoast, fawning journalism of personal editors." Because of the Rocky Shimpo's forthrightness, it got vilified by a paper like the Colorado Times, for which firmness and fairness were lower priorities than flattering the community and gaining its goodwill. "This situation," accused Omura, "is accentuated by our violent enemies, such as the Yasuis, who inaccurately report statements we make before public groups and clothe them in language to incite resentment and aggravate ill feelings." A particularly "vicious example" was Yasui's attempt to attribute to Omura the "patently false and absolutely untrue" allusion that none of the Nisei leaders in Denver are any good at all. "We have labeled this statement," explained Omura, "a lie. Mr. Yasui has threatened to sue us unless we retract. We have refused to retract. The next move is Mr. Yasui's."

Omura’s editorial swan song, titled "Not without Regret," appeared in the Rocky Shimpo's December Is edition. He regretted that his plan to put the newspaper on a sound financial footing had never been implemented. He regretted, too, his stepping down from his post on the basis of sheer "nostalgia," for he was among those people "who live, breathe and virtually eat journalism." He was sorry, practically speaking, that his exit was prompted by the declining fortunes of the Nisei vernaculars in Denver (compared to the boom wartime years), owing to the escalating competition posed by their revitalized West Coast counterparts. Furthermore, he was doleful that at this late juncture the English-language sections of the vernaculars, in spite of having an important role to play, were still a "financial flop" and a "crummy adjunct" to the Japanese-language sections. He regretted, finally, that the new approach to policy he had introduced in the Rocky Shimpo-cosmopolitanism, principled candor, and progressive democratic reform — had not yet been adopted by other Nisei vernaculars. "The current policies of Nisei newspapers," mourned Omura, "cater to the provincialism of the Nisei and make no effort whatsoever to guide its readers to a broader and more liberal outlook. It is a policy that looks backward and fails to keep pace with the individual intellectuality of the Nisei." 
Predictably, in the December 18 issue of the Colorado Times, Yasui responded to Omura's sweeping indictment of him and his newspaper. He dealt with the last of these matters first. The Colorado Times did not fancy itself as being in the same "grandiose and pretentious" tradition of journalism as Omura claimed for his paper. But the Colorado Times also had not, as charged by Omura, catered to public favor. It believed in factual and objective reporting of the news. Its interest in reporting national and international news was circumscribed by the seeming insignificance of such news to Nisei. Rather, the paper tried to cover news on topics of interest to local Nisei residents, such as discrimination (though never in a "carping" or crusading manner). It also sought to encourage Nisei and put their activities in "the best possible light in order to advance the interests of the Nisei in our community and in our nation."

As for Omura's barbs against him, Yasui expressed amazement that the Rocky Shimpo editor had named him as a "violent enemy." Yasui had considered suing Omura but now felt this action pointless, given his resignation. ${ }^{13}$ It is enough, declared Yasui, that "a disturbing factor in Denver journalism is now gone," and he apologized to the Colorado Times' readership for having subjected them to his quarrels with Omura and the Rocky Shimpo. But if Min Yasui was silent about Jimmie Omura in the Colorado Times for the rest of 1947 , he was hardly through with him.

On December 29 Yasui's Colorado Times column revisited the very issue most responsible for the bad blood between him and Omura-wartime Nisei draft resistance. What provoked Yasui's editorial was President Harry Truman's Christmas granting of amnesty (the restoration of full political and civil rights) to virtually all of the approximately 315 Japanese Americans convicted of violating the Selective Service Act. While never mentioning the name of Jimmie Omura or the Heart Mountain FPC and localizing his concern to the thirty-one pardoned draft resisters from Colorado (mostly former Amache, or Granada, concentration camp inmates), he did implicate the first two parties in his comments. Broadly, Yasui was charitable toward those who had resisted the draft so as "to register a legal protest against evacuation." He emphasized the extenuating circumstances leading to their actions and expressed the belief that the pardons had been "unnecessarily long-delayed." At bottom, however, Yasui's commentary represented a critique of the FPC, Omura, and the Nisei draft resisters. "As a protest against evacuation," pronounced Yasui, "many Nisei listened to the 'latrine gossip' 
that circulated in camps, and decided that they would refuse to answer the draft call." These Nisei, "ill-advisedly, contended that they ought not to be called upon to fulfill their obligations as a citizen until their rights as a citizen were fully restored." Fortunately, the stigma produced for Japanese America by these "draft evaders" was more than offset by the overwhelming number of Nisei who chose to serve their country in the army and sometimes ended up wounded or worse. Yasui then delivered his peroration on Nisei wartime patriotism:

We hope and believe that this will be the last of the Nisei draft evasion cases.

At a time when other Nisei boys were slugging against the enemy, reports of draft violation hit the morale of our Nisei GI's. On the home front, refusal to serve was construed by the public as out-right disloyalty. But now, almost two years later, we believe that this is the end of that sad and shameful story.

A moral that we can safely draw, now that it seems to be completely over and done with, it seems to us, is that as citizens and as human beings, we must first fulfill our obligations to the nation and society before we can legally or socially expect that our complete rights will be granted to us. Let us hope that we, as Nisei, have learned this lesson.

Thus, by the closing of 1947 the dust had cleared sufficiently so that a reasonably astute observer could make sense out of the state of Japanese American affairs in Denver. Omura's retreat to private pursuits removed a formidable if progressive counterweight in the JACL's hegemonic control of public life in Japanese Denver. The existence in Colorado's capital city of a large and active JACL chapter, along with a favorable press (both the Colorado Times, thanks to Min Yasui and Togo Tanaka, and the mainstream Denver Post, courtesy of Bill Hosokawa) to promote its agenda and social gospel, ensured that the JACL would prevail. This prevalence extended, as the moral of Yasui's editorial in the Colorado Times on December 29, I947, well testified, to how the immediate Japanese American past would be configured within (and even outside of) Denver's Nikkei community.

According to the JACL's worldview, the basic lesson Nikkei needed to learn from their World War II history, as dramatized by their 1944 response to the draft, was that unlike other Americans, they were largely bereft of human 
and civil rights and needed to fulfill their national obligations, particularly military service, before these withheld rights would be granted to them. The lesson's subtext was that the JACL's wartime policy of "constructive cooperation" with the U.S. government was prudent, practical, and patriotic, while those who had advocated or practiced resistance on constitutional grounds (that is, Omura, the FPC, and Nisei draft resisters) were misguided, mischievous, or treasonable. The real heroes of Japanese American wartime history, in the eyes of JACL leaders, were those valiant Nisei who carried out their duty by answering the call to enlist voluntarily or allowed themselves to be drafted into the army so that they could "go for broke" for their country. In contrast, dissidents like Jimmie Omura were simply tilting at windmills.

This same JACL-shaped historical narrative was disseminated throughout Japanese America by the organization's newspaper, the Pacific Citizen $(P C)$. One of its two principal interpretive voices was Denver-based columnist Bill Hosokawa, the other being its editor, Larry Tajiri, who moved to Denver and was employed by the Denver Post after the PCs transfer in 1952 from its wartime home in Salt Lake City, Utah, to Los Angeles. The $P C$ was the unofficial voice of early postwar Japanese America. Because Mike Masaoka was a veritable one-man gang lobbying Congress for the JACL-crafted program covering Japanese American rights and benefits, he amplified the $P C$ s version of Japanese American history within a strategic national center. During wartime Masaoka had strongly supported Nisei military service, viewing it as the best way of "proving" their loyalty. The all-Nisei 442nd Regimental Combat Team's first volunteer, Masaoka had served as a public relations officer and in that capacity was a very effective pitchman for the JACL's rendition of Japanese American history.

As for Jimmie Omura, for over three decades following his December I947 resignation from the Rocky Shimpo editorship, he disappeared from Japanese American society and was erased from Japanese American history. He remained a Denver resident but lived apart from the Nikkei community. In 195I Omura remarried another Nisei woman, Karen Haruko Omura (née Motoishi), and together they raised their two boys, Gregg and Wayne. Until illness in the late 1970 forced him into retirement, Omura operated a successful landscaping business and achieved prominence as an executive officer in state and national professional landscaping associations. 


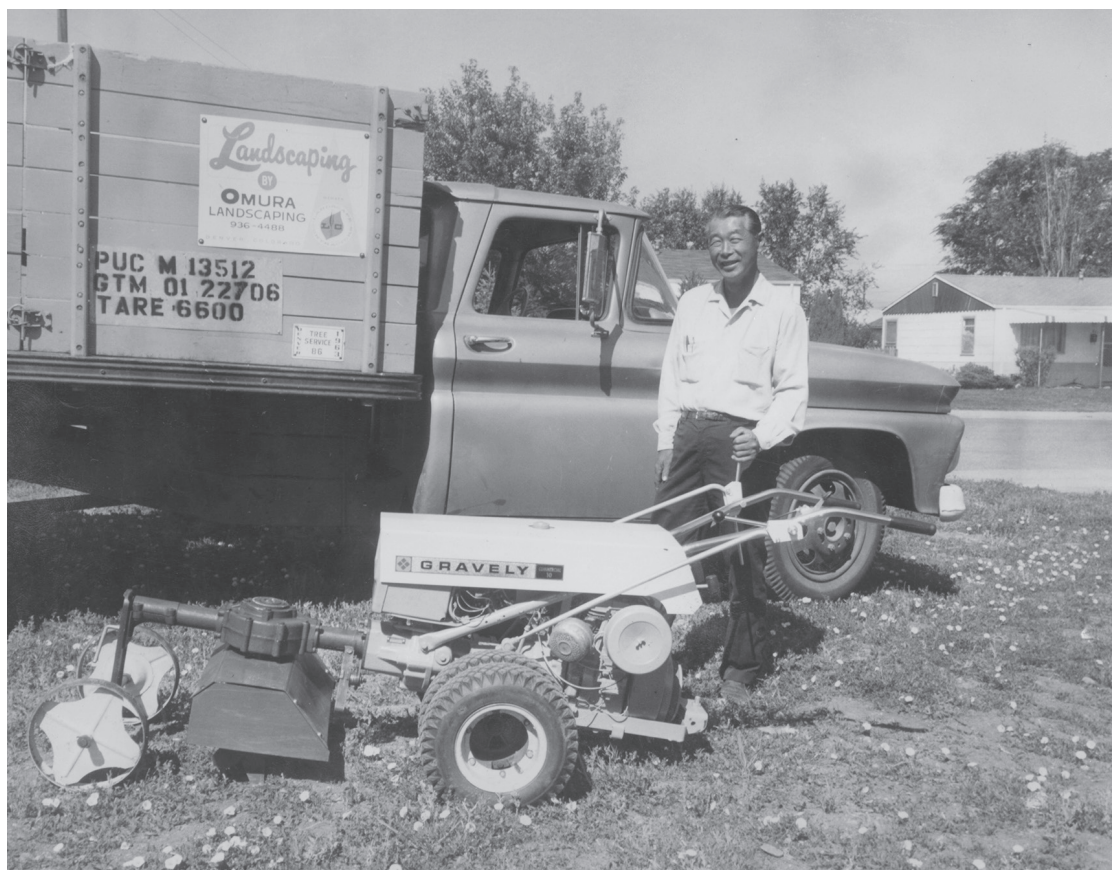

F I G U R E 2. Jim Omura, Omura Landscaping, Denver, Colorado, in the I950s. After resigning the Rocky Shimpo editorship in 1947, Omura devoted himself to building a successful landscaping business. In addition to working on private homes and developments, he also tackled civic projects in the greater Denver area. Omura Papers, Green Library, Stanford University.

The postwar JACL played a key role in expunging Jimmie Omura's name and memory from Japanese American history and consciousness. While he prospered in landscaping, the JACL thrived as an organization. Its expanding membership encompassed the Nisei elite, and outside of Japanese America it was viewed as that community's representative. This situation crystalized as early as 1948, as can be seen through one of JACL advocate Togo Tanaka's Colorado Times columns reprinted in the Pacific Citizen on September 25 that year.

Although Tanaka began his column pointing out how Japanese Americans had been transformed from a despised into an accepted, even respected American minority group, his primary motivation for writing it was to rejoice over the reversed estates of JACLers and anti-JACL resisters since camp 
days. Then, "pressure boys" within such morally defiled places as the War Relocation Authority (WRA) detention centers had intimidated and seduced the Nikkei majority into believing that JACL leaders were informers who had sold out their ethnic community for self-advancement and needed to be punished with beatings and banishment. Having accomplished this objective, resistance "messiahs" were themselves removed from the camps as "troublemakers" and confined to high-security isolation and segregation penal facilities administered by the WRA. According to Tanaka, each of these charismatic resistance leaders, such as Harry Ueno at the Manzanar camp in California (where Tanaka and his family were incarcerated in 1942), had been transformed into "a martyr to his glowing cause." However, opined

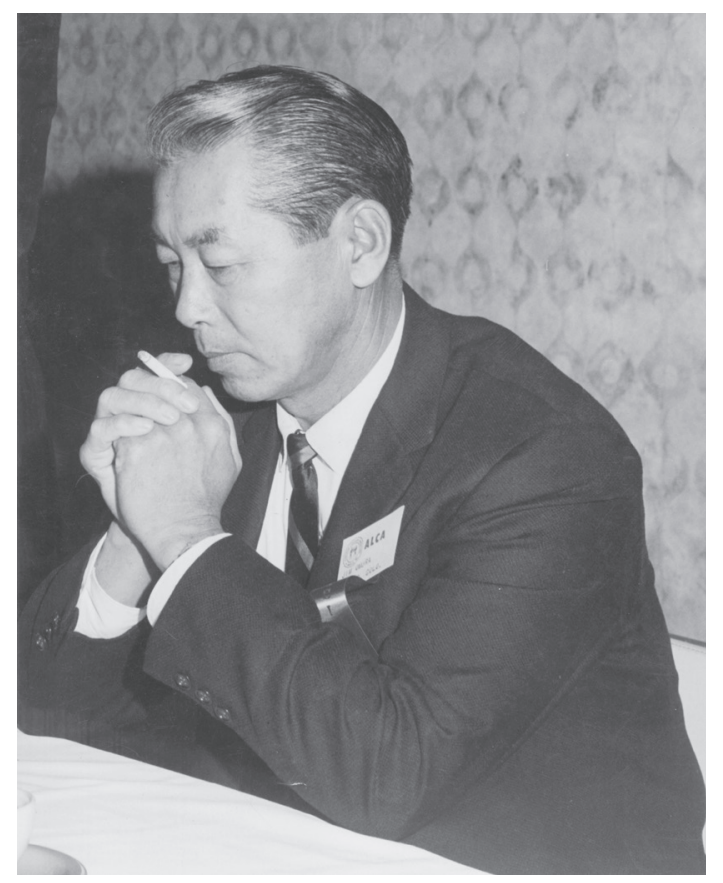

FI G URE 3. In the 1960s, Jim Omura not only was an active member and officer in the Associated Landscape Contractors of Colorado, serving two terms as its president, but also enacted the same roles within the Associated Landscape Contractors of America (ALCA). Here he is shown at the 1967 annual ALCA meeting in Dallas, Texas, discharging his vice-presidential duties. Omura Papers, Green Library, Stanford University. 
Tanaka, posterity would not vindicate them. In fact, just three years after the war it was apparent to him that these individuals had not "contributed anything more than zero to securing the present position of Japanese Americans in U.S. life." After puncturing the historical pretensions of camp resisters, Tanaka turned his pen to obliterating them, via Ueno (the central figure in the so-called Manzanar Riot of December 6, 1942), from the collective memory of Japanese and mainstream America: "This ex-fruit-stand clerk has disappeared into the obscurity and oblivion from which he reared his sallow head, and no one seems to care very much if at all. Thus, the story endeth." ${ }^{14}$

While JACL spokespersons Minoru Yasui and Togo Tanaka were not literally conspiring to oust resisters from the Japanese American World War II story and to refigure the JACL's role in it, they effectively worked in tandem toward those very ends. Whereas Tanaka was exorcising those who had resisted the dismantling of the Nikkei community's traditional cultural arrangements by the alliance between the U.S. government, the WRA, and the JACL, Yasui was extirpating those who had resisted that same alliance's compromising of Nisei citizenship rights.

Neither Yasui nor Tanaka presumed to write books about Japanese American history and its defining World War II experience. However, another prominent JACL leader, Bill Hosokawa (who founded and edited the inmate newspaper at the Heart Mountain detention center in Wyoming), did tackle this task by authoring or coauthoring four interrelated publications: Nisei (1969), ${ }^{15}$ East to America (1980), ${ }^{16}$ JACL in Quest of Justice (1982), ${ }^{17}$ and They Call Me Moses Masaoka (1987). ${ }^{18}$

Setting aside these books' overall quality, what is instructive here is Hosokawa's erasure of resisters from the Japanese American wartime story. Nowhere appears the name of Jimmie Omura. This could hardly have been simply an oversight. Both Hosokawa and Omura had been born and raised in the Seattle, Washington, area, figured significantly in the 1942 Tolan Committee hearings, were associated with Heart Mountain political developments, and resettled in wartime Denver and remained living and working there in the postwar period. Hosokawa does mention draft resisters in the last three of his above-noted books but only perfunctorily and as a foil, variously, to discredit the purported revisionism of historians (like Roger Daniels), ${ }^{19}$ to glorify the compassionate efforts of JACLers (like Minoru Yasui and Joe Grant Masaoka) to "save" the resisters, ${ }^{20}$ and to highlight their meager number and lack of heroic merit relative to Nisei soldiers. ${ }^{21}$ As for 
Harry Ueno and other militant anti-JACL resisters in WRA camps, Hosokawa was also silent, with the single exception of a reference in Nisei to Joe Kurihara, "perhaps the chief agitator in Manzanar."22

Between publication of Hosokawa's Nisei in 1969 and his East to America in 1980, American society and culture, including the Nikkei community, underwent a tumultuous upheaval. As the mounting protests against the Vietnam War, racism, and sexism evinced, passivity and obedience to authority and tradition had ceased being admired. Historians were drawn to outspoken individuals and activist groups who had stood up for social justice and enlarged democratic rights. Moreover, they used this tradition of dissent to promote contemporary developments and personalities. Conversely, they subjected the past's sacred cows-whether individuals, institutions, movements, or events-to rigorous and skeptical scrutiny and, if necessary, strong criticism, and this legacy, too, was put into the service of present-day politics.

This state of affairs vis-à-vis Japanese American history was evident in seminal books by Roger Daniels and Michi Nishiura Weglyn. As Moses Richlin's foreword to Daniels's Concentration Camps USA (I97I) ${ }^{23}$ noted, " $[\mathrm{He}]$ has given special attention to the resistance and protest of the evacuees, an aspect neglected or glossed over by others." ${ }^{24}$ Daniels's acknowledgments discreetly intimated his break with the JACL interpretation: "The late Joe Grant Masaoka . . . would not have agreed with some of my strictures about the Japanese American power structure, but would, I am sure, have defended my right to make them." ${ }^{25}$ Devoting considerable space to the Heart Mountain draft resistance movement and Omura's correlated role, Daniels contrasted his perspective with that of the JACL-WRA.

This account of the "loyal" Japanese American resistance ... calls into question the stereotype of the Japanese American victim of oppression during World War II who met his fate with stoic resignation and responded only with superpatriotism. ... The JACL-WRA view has dominated the writing of the evacuation's postwar history, thereby nicely illustrating E. H. Carr's dictum that history is written by the winners. ... [But] there are those who will find more heroism in resistance than in patient resignation. ${ }^{26}$

Community historian Michi Nishiura Weglyn used similarly bald terminology in her title and text for Years of Infamy (1976). ${ }^{27}$ That book's dust jacket featured the Manzanar camp's controversial plaque blaming "hysteria, racism, and economic exploitation" for the ten WRA "concentration 
camps." As Raymond Okamura's review stated, Weglyn wrote "from the perspective of an outraged victim." She relied heavily on primary sources and "discarded preconceptions," such as benevolent administrative-inmate cooperation, and invested her data with experiential meaning. Her selection of opening photographs coupled "WRA brutality" and the Nikkei response of "defiance and resistance" to such oppressive actions. ${ }^{28}$ Weglyn was mute about the draft resistance movement at Heart Mountain, but for one chapter's epigraph she summoned Omura's Tolan Committee testimony: "Has the Gestapo come to America? Have we not risen in righteous anger at Hitler's mistreatment of the Jews? Then, is it not incongruous that citizen Americans of Japanese descent should be similarly mistreated and persecuted?" ${ }^{29}$ Moreover, Weglyn provided copious, empathetic coverage of camp resisters in all of the WRA camps (including the Moab and Leupp isolation centers for "troublemakers" and the Tule Lake Segregation Center for "disloyals"). ${ }^{30}$ Even her dedication— "To Wayne M. Collins, who did more to correct a democracy's mistake than any other person"-conveyed the book's resistance motif. A civil rights lawyer and social crusader, Collins had been instrumental to the closing of the notorious Tule Lake stockade, ${ }^{31}$ and also spent many postwar years restoring citizenship rights for nearly five thousand Tuleans who had renounced them.

Omura was oblivious to this new resistance historiography. But as an early-I980s retiree, when his public identity as Jimmie Omura was increasingly supplanted by James Omura, he reflected on his journalistic past, including his crusade against the JACL leadership. Plagued by an acute cardiac condition, Omura decided to write his memoirs and emphasize the wartime era. Perhaps, in so doing, he could vindicate the Japanese American community and himself for the damage the U.S. government and the JACL had inflicted on both.

His decision coincided with the Nikkei community's campaign to achieve redress and reparations for its wartime mistreatment. Aware that the congressional Commission on Wartime Relocation and Internment of Civilians (CWRIC) had scheduled I98I hearings within ten U.S. cities, Omura resolved to testify at those being held at his birthplace of Seattle. ${ }^{32}$

During his preretirement days, Omura did not ordinarily maintain a dayby-day diary. However, in the crucial interval roughly spanning his CWRIC testimony on Wednesday, September 9, 198I, in Seattle, and his death on Monday, June 20, 1994, in Denver, Omura faithfully compiled a rather 
meticulous daily journal logging his activities, thoughts, and feelings. The availability of this longitudinal record not only permits his memoir's readers to obtain helpful information bearing on its intellectual and social construction, but also, and of greater moment, affords access to still another consequential period in Omura's life beyond the memoir's restricted chronological domain, wherein he mounted a relentless war of words against the U.S. government and the JACL for their egregious World War II disregard of civil and human rights.

In what follows in this introduction to Omura's memoir, I will draw strategically upon entries from what I have termed the memoirist's "Redress Diary" (supplemented by other relevant source material) to illuminate how the act of representing his life history to posterity simultaneously provided Omura with a propitious opportunity to redress the wartime wrongs that had been suffered by him, personally, his racial-ethnic community, collectively, and the American ideal and practice of constitutional democracy, globally.

By focusing on this tripartite mission within Omura's Redress Diary, I have remained largely silent or cursory about such topics as family and personal relations, financial concerns, political and social affiliations, leisuretime activities, and behavioral idiosyncrasies. Although these concerns are abundantly represented within Omura's diary, I have elected to leave them for contemplation and interpretation by future biographers.

Before turning to the contents proper of James Omura's Redress Diary, perhaps a few words are in order about diaries as a literary genre, followed by some thoughts about how the diary Omura maintained between I98I and 1994 correlates with diary-keeping conventions.

The term "diary" is derived from the Latin word dies, which means "days" and suggests a daily activity, something done day to day. Although classified within the genre of "life writing" or "self-discussion," a diary differs from other forms within this category, such as autobiography, biography, memoir, correspondence, and travel literature, by being more immediate and intimate. The most common type of this genre form is a personal diary, wherein the diarist typically includes her experiences, thoughts, and feelings and often comments as well on current events outside of her direct experience. Generally speaking, a diary is for the diarist's own use and not meant to be read by anyone else. Accordingly, while entries in the diary are 
customarily meticulously dated, simple mechanics such as proper spelling of names and places are accorded less attention. The reasons governing why a person keeps a diary, however, are exceedingly variable, as are the values and uses that a given diarist assigns to his diary's contents.

In comparing Omura's diary to this template for the genre, it does not deviate noticeably in too many particulars. His diary is a carefully dated daily record of his experiences, thoughts, and feelings that also permits a consideration of contemporary events occurring outside of his personal frame of reference. It is assuredly the case, too, that Omura's entries include a fair number of mistakes in spelling and grammar. Still, internal and external evidence combine to make it clear that his entries commonly represent rewrites of earlier scribbled drafts. This practice likely reprised the procedure he had acquired and honed to exactness as a journalist. This is true as well in regard to Omura's penchant for embellishing his entries with precise and nuanced depictions of people, locations, and situations. Moreover, consistent with the fieldwork notes generated by workaday journalists, the entries made by Omura in his diary contain within them the tangible promise of being transmuted into public representation.

This brings us to the mutable qualities of diaries noted above that account for their idiosyncratic character: the diarist's rationale for even sustaining a diary and the worthiness and benefits he imputes to its contents. In Omura's case, his rationale was manifold. For one thing, he wanted to monitor his health, which when he began his diary in I98I was precarious to the point of being life-threatening. For another thing, he wanted to better discipline his mind and more efficiently manage his discretionary time, both of which traits had become derailed somewhat after retirement by a surfeit of televised sports viewing. Also, he desired to regain his former power and fluidity as an expository prose writer. While Omura had written hundreds of articles, essays, op-ed pieces, and the like over his journalistic career, he had never written a book-length manuscript. He at least tacitly realized that if he was to now do so at age sixty-nine, he would have to be health conscious, focused, exercise self-restraint, and write on a very regular and fairly rigorous basis. A diary was certainly not a panacea, but keeping one did have the potential to return dividends for Omura's intended enterprise.

The value and worthiness Omura believed his projected book possessed was to help dramatically revise the standard narrative of the Japanese 
American World War II story, as both an American and a Japanese American event of major historical and contemporary significance. What he was far less sure of when he launched his book project was whether there were a sufficient number of others who shared his belief-particularly Japanese American community members and serious-minded inquirers into the World War II Nikkei experience of whatever racial and ethnic descent or intellectual and political persuasion. It did not take long, however, before his voluminous face-to-face interactions, telephone conversations, and postal exchanges made him acutely conscious that the story he had to tell was widely viewed, most especially by progressive Japanese Americans of all generations, as a spirited vehicle for gaining appropriate redemption.

Perhaps Michi Nishiura Weglyn said it best when she wrote to Omura in mid-1987: "Walter [Weglyn] and I can hardly wait for the publication of your opus. Do stay well and energetic for the sake of our history, for the sake of the shamed, whose self-esteem must be restored." ${ }^{33}$ Increasingly, Omura logged expressions of lofty sentiment like this one into his diary. Doing so, along with reading over such testimonials repeatedly and sharing them selectively with entrusted members of his support community, produced the collateral value of certifying Omura's confidence in what he was doing and of strengthening his determination to complete the job before it was too late to do so. Having finished a draft of his diary only a few days before his death, Omura bequeathed the charge of assessing his memoir's worth (as well as that of his Redress Diary) to posterity.

Among the numerous compliments extended to Omura during the final year of his life, 1994, only a solitary one surfaces in his Redress Diary. In late January, Alex Kajitani of the Nikkei Club at the University of Colorado, Boulder, wrote to Omura to thank him for his presentation to his campus organization, and then added respectfully, "Your achievements and aspirations are an extremely important part of the Japanese American experience." 34

That Omura chose to insert this undergraduate's salute to him into his Redress Diary discloses the distinctive nature of the private-cum-public record that he so devotedly compiled throughout the last thirteen years of his life. Consistent with most garden-variety diarists, Omura enfolded his daily experiences, ideas, and sentiments within his diary. More often, though, his entries corresponded with those logged by special-interest diarists, people dedicated to variable passions (e.g., travel, research, health, family, business, 
gardening, sports, scholarship, or politics). In the case of Omura, his particular special interest, the palpable core of his diary, was clearly redress - for himself, his racial-ethnic community, and his country's governmental polity of constitutional democracy. Accordingly, since Kajitani's formulation conjoined Omura's "aspirations" as well as his "achievements" with the "Japanese American experience," it quite likely struck a responsive redress chord within him.

Personal redress for Omura functioned at multiple levels. Most basically, it embraced identity. For much of his coming-of-age interlude, even his very name had been problematic. In spite of his birth appellation as Utaka Matsumoto, he had become confused as a youth by overhearing Pacific Northwest Issei friends and business associates of his yoshi (adopted) father (Tsurumatsu Matsumoto) address him as "Omura-san." 35 Although by I93I Utaka would assume the name James Matsumoto Omura, as a late-I920s Alaskan cannery worker and Pocatello, Idaho, junior high school pupil he sported a miscellany of monikers: James Matsumoto, James Royal, Jimmy Royal, Jimmie Matsumoto, ${ }^{36}$ Jimmie Hollingworth Royal, ${ }^{37}$ Jimmie Idaho, James Hollingworth Royal, J. Hollingworth Royal, and J. H. Royal. ${ }^{38}$ With the dawning of the I930s, however, he settled permanently on "Jimmie" for his diminutive name, and then in 1943 legally switched his formal name to James Matsumoto Omura. Without dwelling on this jumbled identity in his diary, Omura does succeed in redressing it (that is, putting it to rest) by implicitly yet unequivocally representing himself as James Matsumoto Omura the diarist and Jimmie Omura the journalist.

An identity-related topic that Omura overtly scrutinizes to an extensive degree in his Redress Diary is that of family. In pre-diary years this primary institution had been far more abstract and shadowy than corporeal for him. For one thing, there was his father's nebulous parental origins. Then at age six Omura "lost" his mother (Harue Higashi Matsumoto) and his three younger siblings (two girls, Hanako and Taeko, and a boy, Chikara). When Omura's mother contracted a mysterious disease upon her fourth son's birth, it was decided to have her, plus the two girls and Chikara, go live with family members in Japan, and for Omura and his two older brothers, Yoshito and Kazushi (Casey), to remain with their father on Bainbridge Island. A few years later, eleven-year-old Yoshito was banished permanently by his father from the island because of a juvenile prank he perpetrated against a Caucasian farmer. ${ }^{39}$ Also, upon reaching thirteen, Jimmie himself left home 
to work at a Ketchikan, Alaska, cannery. Thereafter, Omura’s contact with his father was sporadic, with Yoshito practically nil, and with Casey largely episodic, being performed mostly through postal communication until terminated altogether in middle age. For the remainder of his life, Omura never again saw (or even corresponded by mail with) his mother, while the early death of Chikara foreclosed any possible future relationship with him.

Omura's difficult and time-consuming efforts between 198I and 1994 to remedy, or redress, his "orphaned" status is registered intensely in his diary's pages. Therein we witness his resourcefulness, as one who had never set foot in Japan and knew so little Japanese, in ferreting out leads to his two sisters' whereabouts in Japan so as to make contact with them, to flesh out their past and present lives, and to forge a filial bond, however fragile, between them and him. Further, within Omura's late 1990 diary entries, we experience Omura solicitously "reuniting" in Seattle with his recently deceased, tubercular brother Casey, the sibling to whom he had been most connected emotionally and intellectually. ${ }^{40}$ Omura now paid fraternal homage to Casey by settling his modest estate, exchanging remembrances of him with his surviving friends, and arranging for his ashes to be interred in the family sepulcher at the Nagasaki village of Katsusa, Japan. Lastly, in this same vein, we behold Omura's sojourning north from Seattle to Monroe, Washington, to convey news of Casey's death to Matsue Ohmura, the widow of Omura's oldest brother, Yoshito Ohmura, and their children, and in so doing to complete the circle of family redress.

Less poignant perhaps but certainly more powerful than the above varieties of personal redress embedded in Omura's diary was his quest for vocational reclamation as a journalist. It will be recalled that upon resigning his Rocky Shimpo editorship in mid-December 1947 to launch a horticultural career, he had regretted this decision because he counted himself among those people "who live, breathe and virtually eat journalism." Far more than a workaday journalist, Omura was a crusading, conscience-driven one, a member of the press who passionately committed himself to reform causes, especially when they involved matters of civil liberties, historical veracity, legal propriety, or personal and institutional rectitude.

For three postwar decades Omura had placed his perfervid vocational identity on hold while achieving professional and financial success as a landscape contractor. ${ }^{41}$ But after testifying at the 198I CWRIC hearings in Seattle and being encouraged by kindred progressive spirits (mostly within 
but also outside the Japanese American community) to use his pen, as in the distant past, to proclaim truth to oppressive power, Omura increasingly assumed the posture of a reborn journalist fired by the aim of redemption.

In some ways, performing such a role was harder than it had been for him during the World War II era. After all, he had now to contend with both a perilous health condition and writing skills that had become seriously eroded through abject neglect. Additionally, he was woefully out of touch with the general and scholarly literature being published in Asian American and Japanese American studies as well as community developments covered within Nikkei vernacular newspapers and Asian American periodicals. ${ }^{42}$

However, other forces were now at work that tipped the balance in his favor. Whereas before, he had been largely bereft of significant others with whom to share his perspective, he now was gaining a cadre of valued cohorts who empathized with his intents, respected his critical assessments, and applauded his signal contributions to a common cause of historical revision, community revitalization, and social justice. If in the past he had been castigated and even condemned as a pariah, he was now more often celebrated as a courageous patriot. Welcomed back to the pages of the Asian American/Japanese American press by a largely post-Nisei generation of steadily more intrepid editors, Omura not only reclaimed his standing as a journalist, but also garnered acclaim from his peers, as quintessentially exemplified by the lifetime achievement award the Asian American Journalists Association bestowed upon him in 1989. For Omura, this action, as reverberated in his diary, most definitely represented a formidable species of vocational redress.

As a plenitude of entries in his diary punctuate, Omura's long and profound alienation from affective membership within the Japanese American community was significantly reduced, if never altogether reversed, during the final thirteen years of his life. Simultaneously, he selectively reconnected with former Nikkei friends and associates and nurtured new relationships with still other compatible Nikkei. This development occurred not merely in the West Coast areas of Los Angeles, San Francisco, and Seattle, but within the midwestern region of Chicago as well, and even within his uneasily adopted province of Denver. Because so many of these people aided and comforted him and were his coparticipants in reinterpreting American and Japanese American life, Omura largely ceased feeling himself to be the 
proverbial "odd man out." Without extinguishing his singularity as a Nikkei resister, he was enfolded into the comparatively secure ranks of a community of resisters, the majority of whose affiliates were similarly forthright reformist Americans of Japanese ancestry. Membership in such a mostly caring and transparent community blunted the sharp pangs of Omura's estrangement and allowed him to concentrate his time and energy on redressing the wrongs that the security-obsessed U.S. government, in conjunction with the accommodating and opportunistic JACL leadership, had wreaked on his racial-ethnic community.

Omura's preoccupation with redressing the damage suffered by the Japanese American community pervades his diary entries. Whether he is discussing his review of books, such as Bill Hosokawa's JACL in Quest of Justice and Mike Masaoka's They Call Me Moses Masaoka; his assessment of an exhibition script, like the Smithsonian Institution's “A More Perfect Union”; his evaluation of a commissioned institutional inquiry, as with Deborah Lim's The Lim Report; or his reaction to a public commemoration, for example the erection of an honorific statue of Minoru Yasui in Denver's Sakura Square, the Nikkei community redress theme is always paramount.

What ties the above items together is Omura's overarching disdain for how the JACL's self-serving hegemonic version of Japanese American history sacrificed inconvenient truth on the altar of pragmatic invention. Using words as his weapon, Omura ripped away the authority of JACL spokespersons. Thus, in his review of the Hosokawa volume, which he first encountered in a Los Angeles hospital bed in 1982, Omura acidly inveighs, "There are errors in interpretation and misleading premises predicated either on lack of information or altered to suit the author's purpose." Likewise, Omura launches his Masaoka autobiography review essay, which was emphatically rebuffed by a legion of periodicals, with this merciless reproach: "History indeed is infinitely the poorer and literature thereby greatly diminished by publication of this fabricated account of the historic Japanese American episode of World War II."

While Omura's denunciation of Masaoka's "dramatic story of a Japanese American devoted to the welfare of his people in this country and in the land of his ancestry" ${ }^{\prime 3}$ and the JACL story by Hosokawa (who also coauthored the Masaoka memoir) was exacerbated by mutual animosity, his reaction to these works transcended the provincial realm of personal relations. What outraged Omura (and his support community) was what 
such purportedly "historical" literature screened or cagily finessed-that the JACL, the nominal leaders of Japanese America, had collaborated with the U.S. government in the eviction and detention of their own racial-ethnic population. It also galled Omura and his "ilk" that the JACL leadership had so zealously embraced their collaboration as an action undertaken "willingly," "gladly," "cheerfully," and "happily." Such words of "gutless servility," as deemed by Omura, cut deeply into the sensibility of Nikkei and forever remained "a constant reminder of our humiliation [as a people] . . . deceived into being pied-pipered into concentration camps." ${ }^{44}$ It was why he, as opposed to Masaoka and Hosokawa, never regarded monetary redress as something "cheapening" Nikkei but instead chose to champion the highstakes brand of judicial redress pursued by the William Hohri-led National Council for Japanese American Redress. It was also why Omura scorned the JACL's expurgated version of the Lim Report as "another JACL hoax," ${ }^{45}$ and toiled so diligently to both sanction and refine Deborah Lim's unvarnished, highly critical inquiry into the JACL's controversial wartime conduct.

As for the Smithsonian exhibition and the Yasui statue, Omura's concern with them, as rendered in relatable diary entries, was prompted chiefly by matters of a constitutional nature. ${ }^{46}$ Opened to the public on October I, 1987, the exhibition "A More Perfect Union" for the bicentennial of the Constitution was fittingly subtitled "Japanese Americans and the U.S. Constitution." Nonetheless, the subject focus of this exhibition, to be curated by Tom Crouch, was confounded at its 198I conception. This was because it was expected to be a conversion of an earlier exhibition that the Go for Broke veteran's organization had mounted at San Francisco's Presidio Army Museum on the heroic World War II exploits of the 442nd Regimental Combat Team.

In the spring of 1986, when Japanese American activists were expressing discontent that the Smithsonian's advisory committee was dominated by Nikkei and non-Nikkei veterans, one of the committee's few nonveteran members who shared the activists' concerns, Aiko Herzig Yoshinaga, distributed copies of the exhibit script to selected activists, including Omura, and requested them to send the committee feedback as to how the emphasis on the military experience might be best counterbalanced. Omura honored this request and in the following year provided Crouch with a detailed constructive critique of the script. Remonstrating that the script bordered on being propaganda, he took particular exception to its contention that "the 
JACL had traditionally fought for the rights of Japanese Americans" and its avowal that the JACL had no other choice in 1942 but to cooperate with the government in the mass exclusion and incarceration of Japanese Americans. Omura also reminded Crouch that the JACL had opposed test cases challenging the constitutionality of wartime actions against Japanese Americans. Moreover, he compared this behavior against that of the Heart Mountain Fair Play draft resisters, who "demonstrated their dedication and fidelity to the fundamental principles enunciated in our sacred Constitution," and the twenty-one court-martialed Japanese American military resisters who "questioned confinement [by the U.S. government] of their family members in concentration camps while requiring them to submit to their supreme sacrifice in the field of battle. ${ }^{\prime 7}$ Surely, concluded Omura, in a script so weighted with military achievements, room should be provided for stories like these and others that squared more directly with the exhibit's explicit constitutional theme. This situation for him was a glaring shortcoming that required redress. ${ }^{48}$

With respect to the Yasui statue proposed for installation in Denver's Sakura Square, Omura's discontent with such an action also revolved around constitutional matters. Yasui spent nine months in solitary confinement within Portland, Oregon's Multnomah Jail after having challenged unsuccessfully in the courts the constitutionality of his arrest for violating the dusk-to-dawn curfew that General John DeWitt, in the wake of Executive Order 9066 on February 19, 1942, had imposed upon Americans of Japanese ancestry living within designated military borders. His Supreme Court test case also earned for Yasui, a JACL member, the enmity of that organization's leadership, which not only resented such actions but also labeled Yasui a self-styled martyr and called into question his loyalty as a U.S. citizen.

Upon Yasui's release from jail, he was remanded to the Minidoka Relocation Center in Idaho, where he enjoyed the reputation as a champion of civil rights. Then, in early 1944, following the government's reactivation of the military draft for Nisei, Yasui became an ardent defender of this policy, telling Nisei in an open letter that they should "welcome" the draft and not try to evade this responsibility of citizenship. He also circulated a petition that committed Nisei to serve in the military in return for restoration of certain designated citizenship rights, though this restoration was tendered as a request rather than demanded as a precondition. "We feel," stated the 
petition, "that the cheerful and willing assumption of our obligations as American citizens reciprocally calls for the unequivocal restoration of our full citizenship rights." ${ }^{49}$

Shortly after having made this overture of reconciliation to the JACL, Yasui left Minidoka and, after a brief stay in Chicago, resettled in Denver, where he solidified his institutional allegiance. Omura believed that Yasui also developed a close working relationship in Denver with the offices of the WRA, the federal marshal, and the FBI. In the early spring of 1944 Yasui became angered by Omura's Rocky Shimpo series of incisive editorials that supported not only the Heart Mountain Fair Play Committee's doubting of the legality and decency of imposing the draft on imprisoned Nisei, but also its correlated intention to prepare a test case to determine this action's constitutionality. Yasui principally blamed Omura's editorials for the fact that a growing number of draft-age Heart Mountain Nisei had chosen not to report for their draft physicals and thus were confined in county jails throughout Wyoming to await their impending federal court trial in Cheyenne for draft evasion. This led an aggravated Yasui to pay a mid-April visit to Omura's newspaper office. On that occasion, as recalled by Omura four decades later, "Min Yasui said to me, 'I'm going to see you go to prison one way or another." 50

In rapid succession thereafter, two related developments ensued: the Rocky Shimpo's federal alien property custodian threatened to close the paper down if Omura was not at once removed as editor, leaving him no other choice but to resign, which he did on April I8; and Yasui, along with fellow JACLer Joe Grant Masaoka, in April and May, conducted interviews with Nisei "draft delinquents" at the Cheyenne County Jail. It was the U.S. attorney for the District of Wyoming, Carl Sackett, who approved the YasuiMasaoka duo's request to undertake their mission. As the person who had drafted an indictment that a grand jury returned, sealed, on May IO, I944, charging seven FPC leaders and Omura with "conspiring to counsel, aid, and abet" draft-age Heart Mountain men to evade conscription, Sackett hoped that he might secure "intelligence" to assist him in the successful prosecution of this case. Although the desired result did not materialize, the conduct of the interviews by Yasui and Masaoka and the report they sent to the WRA, JACL, and very possibly the U.S. attorney and the FBI left little doubt that "Joe Masaoka and Min Yasui of the JACL had lent a helping hand not just in fighting the spread of draft resistance in the internment 
camps, but also in jailing the resisters, their leaders, and a newspaperman who had dared to criticize their organization." ${ }^{1}$

Mulling over all this in his diary in 1990, only four years after the National JACL Committee on Redress's chair had been none other than Minoru Yasui, apparently hardened Omura's conviction that Yasui was decidedly not a Nikkei civil rights hero meriting a memorial statue in Sakura Square.

This perfervid belief also no doubt deepened Omura's resolve, and that of many of his allied community of resisters, that Japanese Americans warranted redress from the JACL for the damage that its leadership had irresponsibly inflicted upon them through its wartime decisions and actions. It was this sentiment, of course, that constituted the driving force for the construction by James Omura of both his Redress Diary ${ }^{52}$ and the memoir, Nisei Naysayer, that you are about to read. 
This page intentionally left blank 